Jurnal Kesmas Asclepius

Volume 1, Nomor 2, Desember 2019

e-ISSN: 2684-8287

p-ISSN: 2656-8926

DOI: https://doi.org/10.31539/jka.v1i2.922

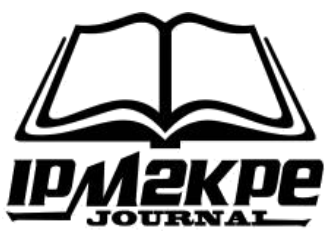

\title{
IMPLEMENTASI KEPERAWATAN DENGAN PENGENDALIAN DIRI KLIEN HALUSINASI PADA PASIEN SKIZOFRENIA
}

\author{
Juli Andri ${ }^{1}$, Henni Febriawati ${ }^{2}$, Panzilion ${ }^{3}$, Selvia Novita Sari ${ }^{4}$, \\ Diko Anandika Utama ${ }^{5}$ \\ Universitas Muhammadiyah Bengkulu 1,2,3,4,5 \\ juliandri@umb.ac.id
}

\begin{abstract}
ABSTRAK
Tujuan dari penelitian ini untuk mengetahui pengaruh implementasi keperawatan dengan pengendalian diri klien halusinasi pada pasien skizofrenia di Rumah Sakit Khusus Jiwa Soeprapto Provinsi Bengkulu. Desain penelitian yang digunakan adalah quasi eksperiment dengan pendekatan one group pre-test andpost-test design. Hasil penelitian ini didapatkan nilai $\mathrm{p}=0,001<\alpha 0,05$ yang artinya terdapat pengaruh imlementasi keperawatan dengan pengendalian diri klien halusinasi pada pasien skizofrenia di Rumah Sakit Khusus Jiwa Soeprapto Provinsi Bengkulu. Simpulan, ada pengaruh imlementasi keperawatan dengan pengendalian diri klien halusinasi pada pasien skizofrenia di Rumah Sakit Khusus Jiwa Soeprapto Provinsi Bengkulu.
\end{abstract}

Kata Kunci: Halusinasi, Implementasi Keperawatan, Pengendalian Diri

\section{ABSTRACT}

The purpose of this study was to determine the effect of implementing nursing with hallucinatory client self-control in schizophrenic patients at Soeprapto Mental Hospital in Bengkulu Province. The research design used was quasi experiment with one group pre-test and post-test design approaches. The results of this study obtained a value of $p$ $=0.001<\alpha 0.05$, which means there is an influence of nursing supplementation with hallucinatory client self-control in schizophrenic patients at the Soeprapto Mental Hospital in Bengkulu Province. Conclusion, there is the effect of nursing supplementation with hallucinatory client self-control in schizophrenic patients at Soeprapto Mental Hospital in Bengkulu Province.

Keywords: Hallucinations, Implementation of Nursing, Self-Control 


\section{PENDAHULUAN}

Kesehatan jiwa bagian tidak terpisahkan dari kesehatan atau bagian integral dan merupakan unsur utama dalam menunjang terwujudnya kualitas hidup manusia yang utuh. Kesehatan jiwa sebagai suatu kondisi yang memungkinkan perkembangan fisik, intelektual dan emosional yang optimal dari sesorang dan perkembangan itu berjalan secara selaras dengan keadaan orang lain. Dengan kata lain sehat jiwa bukan sekedar terbebas dri gangguan jiwa, tetapi merupakan sesuatu yang dibutuhkan oleh semua orang, mempunyai perasaan sehat dan bahagia serta mampu menghadapi tantangan hidup dan dapat menerima orang lain sebagai adanya dan mampunyai sikap positif terhadap diri sendiri dan orang lain (Sumiati et al., 2009).

Proses keperawatan sering disebut suatu metode yang sistematis dan terorganisasi dalam pemberian asuhan keperawatan yang difokuskan pada reaksi dan respon unik individu pada suatu kelompok atau perorangan terhadap gangguan kesehatan yang dialami, baik aktual maupun potensial. Proses keperawatan juga dapat diartikan sebagai pendekatan yang digunakan perawat dalam memberikan asuhan keperawatan sehingga kebutuhan dasar klien dapat terpenuh (Ginting, 2013).

WHO memperkirakan 450 juta orang diseluruh dunia mengalami gangguan jiwa saat ini dan (25\%) penduduk diperkirakan akan mengalami gangguan jiwa pada usia tertentu selama hidupnya. Berdasarkan hasil riset kesehatan dasar tahun 2013, angka rata-rata nasional gangguan mental emosional pada penduduk usia 15 tahun ke atas yaitu 6\%, angka ini setara dengan 14 juta penduduk. Sedangkan gangguan jiwa berat, rata-rata sebesar $0,17 \%$ atau setara dengan 400.000 penduduk. Berdasarkan dari data tersebut menunjukkan bahwa data pertahun di Indonesia yang mengalami gangguan jiwa selalu meningkat (Riskesdas, 2013).

Hasil dari riset kesehatan dasar prevalensi gangguan jiwa berat pada penduduk Indonesia 1,7 per mil dan gangguan mental emosional di Indonesia 6,0 persen (Kemenkes RI, 2013). Lebih mengejutkan lagi tidak kurang dari 4\% dari jumlah tersebut terlambat berobat dan tidak terobati secara berkelanjutan salah satu sebabnya adalah kurangnya layanan untuk penyakit gangguan jiwa. Ekonomi dunia yang sedang mengalami krisis ekonomi juga sangat mempengaruhi meningkatnya penderita gangguan jiwa di dunia, khususnya di Indonesia yang diperkirakan terdapat setidaknya 50 juta atau $25 \%$ dari penduduk Indonesia mengalami gangguan jiwa, diantaranya adalah skizofrenia (Rabba et al., 2014).

Area khusus dalam praktik keperawatan yang menggunakan ilmu tingkah laku manusia sebagai dasar dan menggunakan diri sendiri secara terapeutik dalam meningkatkan mempertahankan, memulihkan kesehatan mental klien dan kesehatan masyarakat dimana klien berada dan termasuk juga klien halusinasi sering juga disebut dengan keperawatan jiwa (Damaiyanti, \& Iskandar, 2012).

Gangguan jiwa suatu ketidakberesan kesehatan dengan manifestasi psikologis atau perilaku terkait dengan penderitaan yang nyata dan kinerja yang buruk dan disebabkan oleh gangguan biologis, sosial, psikologis, genetik, fisis atau kimiawi. Gangguan jiwa mewakili suatu keadaan tidak beres yang berhakikatkan penyimpangan dari suatu konsep normatif. Setiap jenis ketidakberesan kesehatan itu memiliki tandatanda dan gejala-gejala yang khas (Kurniawan, 2016). Ginting (2013) juga menjelaskan bahwa gangguan jiwa merupakan suatu ketidak beresan kesehatan dengan manifestasimanifestasi psikologis atau perilaku terkait dengan penderitaan yang nyata dan kinerja yang buruk dan disebabkan oleh gangguan biologis, sosial, psikologis, genetik, fisis, atau kimiawi. Gangguan jiwa mewakili suatu keadaan tidak beres yang berhakikatkan 
penyimpangan dari suatu konsep normatif. Setiap jenis ketidakberesan kesehatan itu memiliki tanda-tanda dan gejala-gejala yang khas.

Pasien skizofrenia juga biasanya akan merasakan gejala- gejala seperti halusinasi, distorsi isi pikir (waham), distorsi dalam proses pikir dan bahasa dan distorsi perilaku dan pengontrolan diri, keterbatasan dalam ekspresi emosi, keterbatasan dalam produktifitas berpikir (Suryani, 2013). Hal yang sama dijelaskan oleh Kaplan \& Sadock (2007) penderita skizofrenia akan mengalami gangguan dalam kognitif, emosional, persepsi serta gangguan dalam tingkah laku (Maryatun, 2013). Distorsi pikiran negatif yang muncul pada klien skizofrenia dapat memicu timbulnya tekanan mental yang akan berakibat pada timbulnya kecemasan, depresi atau bahkan dorongan untuk bunuh diri.

Halusinasi merupakan salah satu gejala yang sering ditemukan pada klien dengan gangguan jiwa, halusinasi sering diidentikkan dengan skizofrenia. Dari seluruh klien skizofrenia sebagian besar diantaranya mengalami halusinasi. Gangguan jiwa lain yang juga disertai dengan gejala halusinasi adalah gangguan manik depresif dan delerium. Halusinasi merupakan gangguan persepsi dimana klien mempersepsikan sesuatu yang sebenarnya tidak terjadi. Suatu penerapan panca indra tanpa ada rangsangan dari luar. Suatu penghayatan yang dialami suatu persepsi melalui panca indra tanpa stimulus eksteren persepsi palsu (Keliat \& Akemat, 2007).

Tingginya angka penderita gangguan jiwa yang mengalami halusinasi merupakan masalah serius bagi dunia kesehatan dan keperawatan di Indonesia. Penderita halusinasi jika tidak ditangani dengan baik akan berakibat buruk bagi klien sendiri, keluarga, orang lain dan lingkungan. Tidak jarang ditemukan penderita yang melakukan tindak kekerasan karena halusinasinya (Ginting, 2013).

Upaya optimalisasi penatalaksanaan klien dengan skizofrenia dalam menangani gangguan halusinasi di rumah sakit antara lain melakukan penerapan standar asuhan keperawatan, terapi aktivitas kelompok dan melatih keluarga untuk merawat pasien dengan halusinasi. Strategi pelaksanaan pada pasien halusinasi mencakup kegiatan mengenal halusinasi, mengajarkan pasien menghardik halusinasi, minum obat dengan teratur, bercakap-cakap dengan orang lain saat halusinasi muncul, serta melakukan aktivitas terjadwal untuk mencegah halusinasi (Keliat et al., 2006; Devy et al., 2017).

Pemberian implementasi keperawatan untuk membantu klien mengatasi halusinasinya dimulai dengan membina hubungan saling percaya dengan klien. Saling percaya sangat penting dijalin sebelum mengintervensi klien lebih lanjut. Pertama-tama klien harus difasilitasi untuk memperoleh rasa aman dan nyaman untuk menceritakan pengalaman halusinasinya sehingga informasi yang berkaitan tentang halusinasinya dapat komprehensif. Untuk itu perawat harus memulai memperkenalkan diri, menjelaskan tujuan interaksi, membuat kontrak asuhan keperawatan, memperlihatkan sikap sabar, penerimaan yang tulus dan aktif mendengar. Hindari menyalahkan atau respon tertawa saat klien menceritakan pengalaman aneh yang menggelikan (Kusumawati \& Hartono, 2012).

Hasil dari wawancara dari beberapa perawat di ruangan mengatakan bahwa pemberian implementasi keperawatan di ruangan sudah dilakukan pada beberapa pasien namun masih ada beberapa pasien yang belum dapat mengendalikan diri dari halusinasi yang dialaminya setelah dilakukan implementasi. 


\section{METODE PENELITIAN}

\section{Jenis dan Rancangan Penelitian}

Desain penelitian yang digunakan adalah eksperiment dengan pendekatan one group pre-test and post-test design. Dalam desain ini terdapat satu kelompok perlakuan dengan adanya pengukuran awal, kemudian pemberian perlakuan, dan pengukuran setelah diberikan perlakuan.

\section{Waktu dan Lokasi Penelitian}

Penelitian ini dilakukan di Rumah Sakit Khusus Jiwa Soeprapto Provinsi Bengkulu yang merupakan rumah sakit jiwa terbesar dan satu-satunya yang ada di Provinsi Bengkulu. rumah sakit ini mempunyai populasi yang cukup banyak. Rumah sakit ini menampung banyak pasien gangguan jiwa seperti skizofrenia termasuk didalamnya halusinasi, waham, penyalahangunaan obat terlarang dan gangguan jiwa yang lainnya. Penelitian ini mengambil seluruh ruangan di Rumah Sakit Khusus Jiwa Soeprapto Provinsi Bengkulu.

\section{Populasi dan Sampel}

Populasi seluruh pasien skizofrenia di Rumah Sakit Jiwa Soeprapto Provinsi Bengkulu yang berjumlah 1620 orang terdiri dari laki-laki 1254 dan perempuan 366 orang dan jumlah pasien halusinasi 903 orang yang terbagi di beberapa ruangan rawat inap. Sampel dalam penelitian ini adalah seluruh pasien skizofrenia dengan gangguan persepsi sensori halusinasi yang belum pernah mendapatkan pemberian implementasi keperawatan jiwa yang berjumlah 10 orang dan berada dir ruangan IPC.

\section{Teknik Pengumpulan Data}

Data primer yang diambil dari responden dengan cara pemberian implementasi secara langsung di Ruangan Rumah Sakit Khusus Jiwa Soeprapto Provinsi Bengkulu. Dan data sekunder didapat dari dokumen hasil rekam medik Rumah Sakit Khusus Jiwa Soeprapto Provinsi Bengkulu.

\section{Teknik Analisis Data}

Untuk melihat pengaruh intervensi keperawatan dengan pengendalian diri pada klien halusinasi. Data dianalisis dengan menggunakan uji statistik $T$ dependent karena membandingkan data yang berasal dari kelompok data yang berpasangan. Dengan tingkat kepercayaan $95 \%$ atau $\alpha=0,05$.

\section{HASIL PENELITIAN \\ Kemampuan Pengendalian Diri Sebelum dan Sesudah Implementasi}

Tabel. 1

Distribusi Frekuensi Hasil Observasi Sebelum dan Sesudah Diberikan Implementasi

\begin{tabular}{llcccc}
\hline No & Kemampuan & \multicolumn{2}{c}{ Sebelum } & \multicolumn{2}{c}{ Sesudah } \\
& pengendalian diri & frekuensi & persentase & Frekuensi & Persentase \\
\hline 1 & Tidak mampu & 8 & $80 \%$ & 3 & $30 \%$ \\
2 & Mampu & 2 & $20 \%$ & 7 & $70 \%$ \\
Jumlah & 10 & $100 \%$ & 10 & $100 \%$ \\
\hline
\end{tabular}


Berdasarkan tabel 1 dapat dilihat bahwa dari 10 klien, terdapat 8 orang klien $(80 \%)$ dikatakan tidak mampu dalam melakukan pengendalian diri dan 2 orang klien $(20 \%)$ dikatakan mampu melakukan pengendalian diri. Hal ini menunjukkan bahwa lebih banyak klien yang tidak mampu melakukan pengendalian diri dikarenakan belum mendapatkan implementasi keperawatan jiwa sedangkan sesudah implementasi dapat dilihat bahwa dari 10 klien, terdapat 3 orang klien (30\%) dikatakan tidak mampu dalam melakukan pengendalian diri dan 7 orang klien $(70 \%)$ dikatakan mampu melakukan pengendalian diri. Hal ini menunjukkan bahwa kemampuan pengendalian diri klien dapat meningkat karena diberikan strategi pelaksanaan untuk mengendalikan halusinasi klien, sehingga klien mampu untuk mengontrol halusinasinya dan melakukan pengendalian diri dikarenakan telah mendapatkan implementasi keperawatan jiwa.

Tabel. 2

Pengaruh Implementasi Keperawatan dengan Pengendalian Diri Klien Halusinasi pada Pasien Skizofrenia

\begin{tabular}{|c|c|c|c|c|c|}
\hline $\begin{array}{l}\text { Kemampuan pengendalian } \\
\text { diri }\end{array}$ & $\mathrm{N}$ & Mean & SD & SE & P.Value \\
\hline Sebelum & 10 & 7,80 & 1,549 & 0,490 & \multirow{2}{*}{0,000} \\
\hline Sesudah & 10 & 11,50 & 2,273 & 0,719 & \\
\hline
\end{tabular}

Berdasarkan tabel 2 menunjukkan bahwa rata-rata pengendalian deviasi 1,549. Sedangkan untuk rata-rata sesudah dilakukan implementasi adalah11,50 dengan standar deviasi 2,273. Hasil uji statistik didapatkan $\mathrm{p}$ value $=0,000$ berarti $\mathrm{p}$ value $<\alpha=0,05$ yang artinya ada pengaruh implementasi keperawatan dengan pengendalian diri klien halusinasi pada pasien skizofrenia. Sehingga dapat disimpulkan bahwa ada pengaruh implementasi keperawatan dengan pengendalian diri klien halusinasi pada pasien skizofrenia di Rumah Sakit Khusus Jiwa Soeprapto Provinsi Bengkulu.

\section{PEMBAHASAN}

Hasil penelitian didapatkan rata-rata pengendalian diri klien halusinasi sebelum implementasi adalah 7,80. Sedangkan untuk rata-rata sesudah dilakukan implementasi adalah 11,50. Hasil uji statistik menunjukkan bahwa ada pengaruh implementasi keperawatan dengan pengendalian diri klien halusinasi pada pasien skizofrenia.

Menurut Yosep (2010) diperkirakan klien dengan skizofren 90\% mengalami halusinasi. Di rumah sakit jiwa jumlah pasien yang dirawat dengan skizofrenia cukup tinggi dari awal 2017 menunjukkan 6735 pasien dari semua jumlah pasien yang mengalami gangguan jiwa 3317 diantaranya mengalami halusinasi. Agar dapat meningkatkan kesehatan pasien skizofrenia khususnya halusinasi sangat diperlukan intervensi dini yang komperhensif seperti pengobatan medis dan asuhan keperawatan (Maramis, 2009).

Pada era sekarang kesehatan merupakan hal terpenting dalam menjalani kehidupan sehari-hari. Pasal 1 Undang-Undang Repubik Indonesia nomor 36 tahun 2009 bahwa kesehatan ialah dimana seseorang dalam keadaan sehat untuk memungkinkan setiap orang untuk hidup produktif secara ekonomi dan sosial, baik itu sehat mental, fisik, sepiritual maupun sosial. Kondisi mental seseorang yang sejahtera akan memungkinkan seseorang hidup harmonis dan produktif sebagai dari salah satu bagian kualitas hidup seseorang dengan selalu memperhatikan semua segi kehidupan manusia sehingga semua itu dapat dikatan dengan sehat jiwa. Direktur jendral 
pembinaan kesehatan masyarakat (binkesmas) departemen kesehatan dan juga memperkirakan tidak kurang dari 450 juta penderita gangguan jiwa ditemukan di dunia. Serta dibeberapa negara menunjukkan angka yang mengejutkan yaitu mencapai $8,1 \%$ dari kesehatan global masyarakat mengalami gangguan jiwa (Rabba et al., 2014).

Semua manusia pasti pernah, bahkan acapkali mengalami masalah-masalah yang dapat membuat manusia semakin dewasa, matang, dan cerdas bila dihadapi dengan positive thinking. Namun bila negative thinking yang digunakan, masalah dapat membawa petaka. Disinilah pentingnya positive thinking dalam menghadapi setiap masalah. Bagi orang yang berpikir positif, setiap masalah selalu ada solusi. Semua masalah pasti ada jalan keluarnya (Hidayati, 2010). Orang-orang yang senantiasa berpikir positif akan mampu melihat segala sesuatu dari sudut pandang yang benar, sehingga ia tetap menjaga kesehatan dan kecerdasan emosional secara seimbang. Mereka tidak akan membiasakan diri larut dalam kekecewaan dan kemarahan berkepanjangan (Asmani \& Jamal, 2009; Hidayati, 2010).

Pada pasien-pasien skizofrenia sering muncul pikiran-pikiran negatif dimana pemikiran-pemikiran negatif yang muncul pada klien skizofrenia saat diberikan terapi beraneka ragam, ada yang mengungkapkan masalah tentang dirinya yang mungkin tidak dapat menikah karena kondisi mereka yang berdiagnosis skizofrenia, ada yang mengungkapkan tentang masalah keluarga yang membuat mereka merasa tidak berdaya (tidak berguna) ada juga yang mengungkapkan tentang ketakutan mereka ditinggal oleh orangtua atau saudara dan lain-lain (Rahmayani \& Syisnawati, 2018).

Pasien skizofrenia juga biasanya akan merasakan gejala- gejala seperti halusinasi, distorsi isi pikir (waham), distorsi dalam proses pikir dan bahasa dan distorsi perilaku dan pengontrolan diri, keterbatasan dalam ekspresi emosi, keterbatasan dalam produktifitas berpikir (Suryani, 2013). Hal yang sama dijelaskan oleh Kaplan \& Sadock (2007) penderita skizofrenia akan mengalami gangguan dalam kognitif, emosional, persepsi serta gangguan dalam tingkah laku (Maryatun, 2013). Distorsi pikiran negatif yang muncul pada klien skizofrenia dapat memicu timbulnya tekanan mental yang akan berakibat pada timbulnya kecemasan, depresi atau bahkan dorongan untuk bunuh diri.

Halusinasi adalah salah satu gejala gangguan jiwa di mana pasien mengalami perubahan sensori persepsi, merasakan sensasi palsu berupa suara, penglihatan, pengecapan perabaan atau penghiduan. Halusinasi juga merupakan salah satu gejala yang sering ditemukan pada pasien dengan gangguan jiwa, Halusinasi sering diidentikkan dengan skizofrenia. Dari seluruh pasien skizofrenia $70 \%$ diantaranya mengalami halusinasi. Gangguan jiwa lain yang juga disertai dengan gejala halusinasi adalah gangguan manik depresif dan delerium. Halusinasi merupakan gangguan persepsi dimana pasien mempersepsikan sesuatu yang sebenarnya tidak terjadi. Suatu penerapan panca indra tanpa ada rangsangan dari luar. Suatu penghayatan yang dialami suatu persepsi melalui panca indra tanpa stimulus eksteren persepsi palsu (Praptoharsoyo, 2012).

Menurut Rabba et al., (2014) halusinasi merupakan bentuk gejala positf yang sangat sering terjadi pada pasien gannguan presepsi. Bentuk halusinasi ini bisa berupa suara-suara yang bising atau mendengung, tapi yang paling sering berupa kata-kata yang tersusun dalam bentuk kalimat yang agak sempurna. Sedangkan menurut Maramis (2009) halusinasi ialah seseorang dalam keadaan sadar melakukan pencerapan tanpa adanya rangsangan apapun pada panca indra. 
Menurut Muhifth (2015) halusinasi merupakan keadaan hilangnya kemampuan individu dalam membedakan rangsangan internal (pikiran) dan rangsangan eksternal (dunia luar). Klien memberi persepsi atau pendapat tentang lingkungan tanpa adanya objek atau rangsangan yang nyata. Contohnya klien mendengar suara padahal tidak ada orang yang berbicara. Gejala gangguan jiwa klien mengalami perubahan persepsi sensori yaitu merasakan sensori palsu berupa suara, penglihatan, pengecapan atau penghiduan.

Menurut Stuart (2007) penyebab terjadinya halusinasi merupakan biologis dimana abnormalitas perkembangan sistem saraf yang berhubungan dengan respon neurobiologis yang maladaptif baru mulai dipahami. Ini menunjukkan penelitian pencitraan otak sudah menunjukkan keterlibatan otak yang lebih luas dalam perkembangan skizofrenia. Lesi pada daerah frontal, temporal dan limkik berhubungan dengan perilaku psikotik. Psikologis merupakan lingkungan klien yang sangat mempengaruhi respon dan kondisi psikologis klien.

Pelaksanaan implementasi keperawatan meliputi strategi pelaksanaan I-II yaitu melatih klien menghardik halusinasi, melatih bercakap-cakap dengan orang lain, melatih klien melakukan aktivitas sehari-hari, melatih klien menggunakan obat. Dari hasil penelitian didapatkan perbedaan pengendalian diri klien halusinasi antara sebelum implementasi dan sesudah implementasi. Implementasi adalah suatu kegiatan yang dilakukan perawat/ pelaksanaan perawat yang dilakukan kepada klien (Afnuhazi, 2015). Dalam melakukan implementasi keperawatan atau tindakan keperawatan disesuaikan dengan rencana tindakan keperawatan yang telah dibuat (Kusumawati \& Hartono, 2012).

Pada penelitian ini, peneliti hanya melakukan strategi pelaksanaan I-II, peneliti hanya ingin mengenalkan cara pengendalian diri yang mudah diterima oleh klien. Klien selalu diamati selang beberapa waktu setelah dilakukannya implementasi keperawatan. Saat melakukan observasi, didapatkan 7 klien lebih memilih bercakap - cakap untuk mengendalikan diri pada saat halusinasi timbul dan 3 klien memilih menghardik. Hal ini sejalan dengan penelitian Ginting (2013) menyatakan penerapan asuhan keperawatan memberikan hasil yang bermakna terhadap peningkatan kemampuan klien mengontrol halusinasinya.

Berdasarkan penelitian Castro (2010) pengaruh pelaksanaan standar asuhan keperawatan halusinasi terhadap kemampuan kognitif dan psikomotor pasien halusinasi dalam mengontrol halusinasi di Ruang Pusuk Buhit Rumah Sakit Jiwa Daerah Sumatera Utara Medan bahwa ada perbedaan cara mengontrol halusinasi antara sebelum dan sesudah dilakukan standar asuhan keperawatan halusinasi.

Penelitian Carolina (2008) tentang pengaruh penerapan standar asuhan keperawatan halusinasi terhadap kemampuan pasien mengontrol halusinasi di RS Jiwa Dr. Soeharto Heerdjan Jakarta menunjukkan bahwa penerapan asuhan keperawatan halusinasi yang sesuai standar dapat membantu meningkatkan kemampuan kognitif dan psikomotor pasien mengontrol halusinasi dan menurunkan intensitas tanda dan gejala halusinasi sehingga dapat menurunkan efek lanjut dari halusinasi yang dialami.

Pelaksanaan intervensi keperawatan klien halusinasi dilakukan agar klien halusinasi mampu mengendalikan halusinasinya dengan cara menghardik halusinasinya, dapat dilakukan dengan melakukan penyangkalan terhadap suara/bisikan yang didengar seperti "saya tidak mau dengar". Bercakap-cakap dengan teman atau perawat dilakukan untuk mengalihkan perhatian klien halusinasi, saat terdengar suara/bisikan dengan 
bercakap-cakap dapat membuat pikiran terfokus pada topik yang dibicarakan sehinggatidak terdengar lagi suara/bisikan yang tidak ada sumbernya.

Menurut penelitian yang dilakukan Damaiyanti \& Iskandar (2012) keperawatan jiwa adalah area khusus dalam praktek keperawatan yang menggunakan ilmu tingkah laku manusia sebagai dasar dan menggunakan diri sendiri secara terapeutik dalam meningkatkan mempertahankan,memulihkan kesehatan mental klien dan kesehatan masyarakat dimana klien berada dan termasuk juga klien halusinasi.

Klien yang mengalami halusinasi sukar untuk mengontrol diri dan sukar untuk berhubungan dengan orang lain. Perawat harus mempunyai kesadaran yang tinggi agar dapat mengenal, menerima dan mengevaluasi perasaan sendiri sehingga dapat menggunakan dirinya secara terapeutik dalam memberikan asuhan keperawatan terhadap klien halusinasi perawat harus bersikap jujur, empati terbuka dan selalu memberi penghargaan namun tidak boleh tenggelam juga menyangkal halusinasi yang klien alami. Tindakan keperawatan, membantu klien mengenali halusinasi, melatih klien mengontrol halusinasi, melatih bercakap-cakap dengan orang lain, melatih klien beraktivitas secara terjadwal (Yosep, 2010).

\section{SIMPULAN}

Ada pengaruh pemberian implementasi dan pengendalian diri klien halusinasi pada pasien skizofrenia di Rumah Sakit Khusus Jiwa Soeprapto Privinsi Bengkulu. Berdasarkan hasil tersebut dapat diambil kesimpulan penelitian yaitu semakin baik pelaksanaan intervensi keperawatan maka pengendalian diri klien halusinasi semakin baik.

\section{SARAN}

\section{Rumah Sakit Jiwa Daerah Provinsi Sumatera Utara}

Bagi Rumah Sakit khusus Jiwa Soeprapto Provinsi Bengkulu lebih meningkatkan pelaksanaan intervensi keperawatan klien halusinasi terhadap klien halusinasi agar klien halusinasi dapat mengendalikan halusinasi dengan baik dan membuat jadwal kegiatan harian klien halusinasi yang baik.

\section{Bagi Institusi Pendidikan Program Studi Ilmu Keperawatan}

Bagi pendidikan keperawatan, terutama mahasiswa agar lebih memahami pelaksanaan intervensi keperawatan klien halusinasi dapat diterapkan lebih baik sehingga dalam pelaksanaan langsung kepada klien halusinasi lebih optimal.

\section{Bagi Peneliti Lainnya}

Bagi peneliti selanjutnya agar mengembangkan dan melanjutkan penelitian dengan jumlah responden yang lebih banyak untuk mendapatkan hasil lebih sempurna dan meneliti tentang faktor-faktor yang berhubungan dengan pelaksanaan intervensi keperawatan terhadap pengendalian diri klien halusinasi dengan menggunakan desain peneltian yang berbeda. 


\section{DAFTAR PUSTAKA}

Afnuhazi, R. (2015). Komunikasi Terapeutik dalam Keperawatan Jiwa. Yogyakarta: Gosyen Publishing

Asmani, A., \& Jamal, M. (2009). The Law of Positive Thinking. Yogyakarta: Gara Ilmu

Caroline, C. (2008). Pengaruh Penerapan Standar Asuhan Keperawatan Halusinasi Terhadap Kemampuan Pasien Mengontrol Halusinasi di RS Jiwa Soeharto Heerdjan Jakarta. Tesis. Tidak Dipublikasikan

Castro, C. (2010). Pengaruh Pelaksanaan Standar Asuhan Keperawatan Defisit Perawatan Diri terhadap Kebersihan Diri di Ruangan Pusuk Buhit Rumah Sakit Jiwa Daerah Provinsi Sumatera Utara Medan. Universitas Sumatera Utara

Damaiyanti, M., Iskandar, I. (2012). Asuhan Keperawatan Jiwa. Bandung: Refika Aditama

Devy, A. E. A., Ruliati, R., \& Muslim, A. (2017). Asuhan Keperawatan Jiwa pada Klien Skizofrenia Paranoid dengan Gangguan Persepsi Sensori Halusinasi Penglihatan Rumah Sakit Jiwa Menur Surabaya. Sekolah Tinggi Ilmu Kesehatan Insan Cendekia Medika Jombang

Ginting, I. (2013). Hubungan Pelaksanaan Intervensi Keperawatan dengan Pengendalian diri Klien Halusinasi. Sumatra Utara, 1-25

Hidayati, A. (2010). Pengaruh Positive Thinking terhadap Kemampuan Menyelesaikan Masalah (Problem Solving) pada Siswa Kelas II Madrasah Aliyah Ma'arif Cepogo, Boyolali. Sekolah Tinggi Agama Islam Negeri Salatiga

Kaplan, K., \& Sadock, S. (2007). Sinopsis Psikiatri: Ilmu Pengetahuan Psikiatri Klinis Jilid. Jakarta: Bina Rupa Aksara

Keliat, B. A., Panjaitan, R. U., \& Helena, N. (2006). Proses Keperawatan Kesehatan Jiwa. Jakarta: Kedokteran EGC

Keliat, S., \& Akemat, S. (2007). Model Praktek Keperawatan Profesional Jiwa. Jakarta: kedokteran EGC

Kemenkes, RI. (2013). Laporan Hasil Riset Kesehatan Dasar (Riskesdas) Indonesia tahun 2013. Jakarta : Badan Penelitian dan Pengembangan Kesehatan Kemenkes RI

Kurniawan, F. (2016). Gambaran Karakteristik pada Pasien Gangguan Jiwa Skizofrenia di Instalasi Jiwa RSUD Banyumas tahun 2015. Banyumas: Fakultas Ilmu Kesehatan UMP

Kusumawati, F., Hartono, Y. (2012). Buku Ajar Keperawatan Jiwa. Jakarta: Salemba Medika

Maramis, M. (2009). Catatan Ilmu Kedokteran Jiwa. Edisi 2. Surabaya: Airlangga

Maryatun, S. (2013). Peningkatan Kemandirian Perawatan Diri Pasien Skizofrenia Melalui Rehabilitasi Terapi Gerak. Palembang: Fakultas Kedokteran

Muhift, A. (2015). Buku Teori dan Aplikasi Pendidikan Keperawatan Jiwa. Yogyakarta

Praptoharsoyo, P. (2012). Asuhan Keperawatan Jiwa. Bandung : Refika Aditama

Rabba, P. E., Dahrianis, D., \& Rauf, S. P. (2014). Hubungan antara Pasien Halusinasi Pendengaran terhadap Resiko Perilaku Kekerasan Diruang Kenari Rs.Khusus Daerah Provinsi Sul-Sel. Jurnal Ilmiah Kesehatan Diagnosis, 4(4), 470-471. http://ejournal.stikesnh.ac.id/index.php/jikd/article/view/2

Rahmayani, A., \& Syisnawati, S. (2018). Mengontrol Pikiran Negatif Klien Skizofrenia dengan Terapi Kognitif. Journal of Islamic Nursing, 3(1), 46-54. http://journal.uin-alauddin.ac.id/index.php/join/article/view/5475/4842 
Riskesdas. (2013). Riset Kesehatan Dasar (Riskesdas) 2013. Laporan Nasional 2013, 1-384. https://doi.org/

Stuart, G. W. (2007). Buku Saku Keperawatan Jiwa. Edisi 5. Jakarta: EGC

Sumiati, S., Nurhaeni, H., Dinarti., \& Aryani, R. (2009). Kesehatan Jiwa Remaja dan Konseling. Jakarta: Trans Info Media

Suryani, S. (2013). Mengenal Gejala dan Penyebab Gangguan Jiwa. Makalah (Seminar Nasional). Bandung: BEM Psikologi UNJANI

Yosep, I. (2010). Keperawatan Jiwa. Bandung: Refia Aditama 